\title{
The bivalves from the Scotia Arc islands: species richness and faunistic affinities*
}

\author{
DIEGO G. ZELAYA \\ Division of Invertebrate Zoology, Museo de La Plata, Paseo del Bosque s/n, 1900, La Plata, Buenos Aires, Argentina. \\ E-mail: dzelaya@museo.fcnym.unlp.edu.ar
}

\begin{abstract}
SUMMARY: Species richness of the shallow-water bivalves from the Scotia Arc islands was studied on the basis of new collections and by reviewing extant information. Seventy-three species are recognised from the entire area. South Georgia, the South Orkney Islands and the South Shetland Islands were similar in species richness to the Antarctic Weddell sector. New records for 51 bivalve species are provided and the presence of 18 undescribed species is reported. The faunistic similarity of the islands of the Scotia Arc to the Magellan region and the Antarctic Weddell sector is re-examined. These islands show a high similarity to the Antarctic Weddell sector (49 to 85\%) and a low similarity to the Magellan region (12 to $32 \%$ ). Evidence from bivalves clearly supports the placement of the Scotia Arc islands within the Antarctic region.
\end{abstract}

Keywords: diversity, biogeography, molluscs, Bivalvia, Scotia Sea, Antarctic.

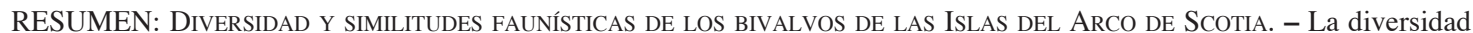
de bivalvos que habitan en las aguas someras del Arco de Scotia fue estudiada sobre la base de recientes colecciones desarrolladas en el área y por la revisión de la información preexistente. Un total de 73 especies fueron reconocidas para el área; el número de especies hallado en las islas Georgias del Sur (49), Orcadas del Sur (43) y Shetland del Sur (42) resultó similar al actualmente conocido para el cuadrante antártico de Weddell (41 especies). Se proporcionan nuevas citas para 51 especies de bivalvos y se informa sobre la existencia de 18 especies aún no descriptas. Las similitudes faunísticas de las islas del Arco de Scotia con la región magallánica y con el cuadrante antártico de Weddell fueron reanalizadas. Estas islas mostraron una elevada similitud con el cuadrante antártico de Weddell (49 a 85\%, dependiendo del archipiélago) y una baja similitud respecto a la región magallánica (12 a 32\%). Las evidencias procedentes de los bivalvos claramente soportan el emplazamiento de las islas del Arco de Scotia dentro de la región antártica.

Palabras clave: diversidad, biogeografía, moluscos, Bivalvia, Mar de Scotia, Antártida.

\section{INTRODUCTION}

Four archipelagos forming the Scotia Arc are located between the southernmost South American mainland and the Antarctica. According to their geological origin and history, two groups of islands are recognised: the first one comprises the old archipelagos originated as a consequence of the fragmentation process of the Gondwana supercontinent,

*Received April 1, 2004. Accepted April 25, 2005.
37 to $20 \mathrm{Ma}$ (i.e. South Georgia, the South Orkney Islands and the South Shetland Islands); the second is a series of younger islands originated by volcanic processes that started about 1-10 million years ago: the South Sandwich archipelago (Dalziel and Elliot, 1971; Birkenmajer, 1984; Gambôa and Maldonado, 1991; Ramos, 1996; Udintsev et al., 2000). The islands of the Scotia Arc provide an outstanding opportunity to study the origin and evolutionary radiation of their fauna, taking into account the intermediate geographic position between South 
America and the Antarctica. Moreover, the study of the fauna from these islands could provide a basis for the understanding of the present faunistic similarities between South America and Antarctica, two continents linked during the Mesozoic and presently geographically separated and isolated by deep water and marine current systems (Dalziel and Elliot, 1971; Crame, 1999).

Based on data from different invertebrate taxa, the Scotia Arc islands were usually included in the Antarctic region (e.g. De Broyer and Jazdzewski, 1993: Amphipoda; Mühlenhardt-Siegel, 1999: Cumacea; Gorny, 1999: Decapoda) but also considered as a member of the Subantarctic region (e.g. Casteló, 1999: Isopoda). A particular situation is found with South Georgia, which has been considered as related either to the Magellan (Linse, 1997: Mollusca) or the Antarctic regions (Carcelles, 1953: Mollusca), as representing a transitional area between these regions (Linse et al., 2003: Mollusca; Schrödl, 1999, 2003: Nudibranchia), or as a distinctive biogeographic unit (Linse, 2002: Mollusca; Powell, 1951: Gastropoda; De Broyer and Jazdzewski, 1993: Amphipoda). Canteras and Arnaud (1985) argued for faunistic affinities of South Georgia with the Kerguelen Islands and Crozet Islands. The sets of data analysed by several authors were heterogeneous; furthermore, the available information on species diversity and their geographical distribution is still fragmentary and in many cases needs revision before it can be included in a biogeographic analysis. Both of these facts seem to be the origin of discrepant interpretations.

Knowledge on the species richness of bivalves from the Scotia Arc islands is fragmentary. The most important contributions for the area were provided by the Discovery, Discovery II and William Scoresby expeditions (Dell, 1964 and 1990). Relevant studies on the fauna from South Georgia were provided by Martens (1885) and Martens and Pfeffer (1886). Dall (1914), David (1934), Soot-Ryen (1951) and Carcelles (1953) provided new localities for some species within the archipelago, and Zelaya and Ituarte $(2002,2003)$ described three new species from these islands. The fauna of the South Orkney Islands was studied by the Scottish National Antarctic Expedition (Melvill and Standen, 1907), from the R/V "Polarstern" and R/V "Walther Herwig" cruises (Mühlenhardt-Siegel, 1989). Preston (1916), Soot-Ryen (1951), Arnaud et al. (1986), Mühlenhardt-Siegel (1989), Arnaud et al. (2001), and Nar- chi et al. (2002) contributed to the knowledge of the fauna from the South Shetland Islands.

Carcelles (1953) and Powell (1960) provided checklists of the Antarctic bivalves (including the Scotia Arc islands), but subsequent studies conducted in Antarctic waters (Dell, 1964, 1990; Hain, 1990; this study) strongly suggest that the information contained in published lists needs to be revised. In this paper the species richness of the shallow water bivalves from the Scotia Arc islands was studied on the basis of recent collections and by reviewing extant information, in order to reanalyse the current biogeographic status of these islands and their relationships with the Magellan region and adjacent Antarctic waters.

\section{MATERIAL AND METHODS}

\section{Sources of information}

The main sources of information for this study were the bivalves collected by R/V "Polarstern" during the "Latin American Polarstern Study" (ANT XXI-5, LAMPOS) in 2002. Sampling took place at 17 sampling stations along the Scotia Sea (for details on stations see Arntz and Brey, 2003). Additional information came from 30 sampling stations off South Georgia worked on the R/V "Eduardo L. Holmberg" during the 1995, 1996, 1997 cruises, and 20 sampling stations in Patagonia (Beagle Channel, Straits of Magellan and east of Tierra del Fuego) visited by the A.R.A. "Alférez Sobral". Other sources of information were molluscs from the following museum collections: Museo de La Plata, La Plata (MLP), Museo Argentino de Ciencias Naturales "Bernardino Rivadavia", Buenos Aires (MACN) and Museo Nacional de Historia Natural, Santiago, Chile (MNHN). Moreover, published information on bivalves from all these areas, as well as that from the Antarctic Weddell sector, was critically reviewed and added to the present analysis.

\section{Terminology}

Throughout this article, the term "Scotia Arc islands" is used to refer to the Scotia Sea archipelagos, i.e. South Georgia, the South Sandwich Islands, the South Orkney Islands and South Shetland Islands. "Antarctic Weddell sector" comprises the Antarctic Peninsula and the Weddell Sea. "Patagonia" is used to refer to the southern tip of South 
TABLE 1. - List of bivalve species and their geographic distribution. X: this study; $\mathrm{X}^{1}$ : new records from this study; *: literature records; ?: presence uncertain; P, Patagonia; M/F, Malvinas / Falkland Is.; SG, South Georgia; SS, South Sandwich Is.; SO, South Orkney Is.; SSH South Shetland Is.;WS, Antarctic Weddell sector.

\begin{tabular}{|c|c|c|c|c|c|c|c|c|}
\hline Family & Species & $\mathrm{P}$ & $\mathrm{M} / \mathrm{F}$ & SG & SS & $\mathrm{SO}$ & SSH & WS \\
\hline Solemyidae & Acharax patagonica (Smith, 1885) & $\mathrm{X}$ & & & & & & \\
\hline \multirow[t]{5}{*}{ Nuculidae } & Ennucula eltanini Dell 1990 & $\mathrm{X}$ & & & & & & \\
\hline & Ennucula georgiana Dell, 1964 & & & $X$ & & & & \\
\hline & Enписula grayi (d’Orbigny, 1846) & $\mathrm{X}$ & ? & & & & & \\
\hline & Nucula falklandica Preston, 1912 & $\mathrm{X}$ & $*$ & & & $?$ & & $?$ \\
\hline & Nucula pseudoexigua Villarroel and Stuardo, 1998 & $\mathrm{X}$ & & & & & & \\
\hline \multirow[t]{3}{*}{ Nuculanidae } & Nuculana (?) inaequisculpta (Lamy, 1906) & & & & & $\mathrm{X}$ & $\mathrm{X}$ & * \\
\hline & Nuculana sulculata (Couthouy in Gould, 1852) & $\mathrm{X}$ & $*$ & & & & & \\
\hline & Propeleda longicaudata (Thiele, 1912) & $\mathrm{X}$ & & $\mathrm{X}$ & & $X$ & $\mathrm{X}$ & * \\
\hline Malletiidae & Malletia cumingi (Hanley, 1860) & $\mathrm{X}$ & $*$ & & & & & \\
\hline Tindariidae & $\begin{array}{l}\text { Malletia magellanica (Smith, 1875) } \\
\text { Tindaria virens Dall, } 1889\end{array}$ & $\begin{array}{l}X \\
*\end{array}$ & & & & & & \\
\hline \multirow{8}{*}{ Yoldiidae } & Yoldia eightsi (Couthouy in Jay, 1839) & $?$ & $?$ & $\mathrm{X}$ & & $\mathrm{X}$ & $\mathrm{X}$ & $\mathrm{X}$ \\
\hline & Yoldia woodwardi Hanley, 1860 & $\mathrm{X}$ & $\mathrm{X}$ & & & & & \\
\hline & $\begin{array}{l}\text { Yoldiella antarctica (Thiele, 1912) } \\
\text { Yoldiella ecaudata (Pelseneer, 1903) }\end{array}$ & & & & $X$ & $\mathrm{X}$ & $X$ & $*$ \\
\hline & Yoldiella granula Dall, 1908 & $\mathrm{X}$ & & & & & & 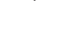 \\
\hline & Yoldiella cf. indolens Dall, 1908 & $\mathrm{X}$ & & & & & & \\
\hline & Yoldiella oblonga (Pelseneer, 1903) & & & & & & & * \\
\hline & Yoldiella valettei Lamy, 1906 & $?$ & $\mathrm{X}$ & & $\mathrm{X}^{1}$ & * & $\mathrm{X}^{1}$ & * \\
\hline & Yoldiella sp. & $\mathrm{X}$ & & & & & & \\
\hline \multirow{2}{*}{ Siliculidae } & Silicula patagonica Dall, 1908 & $\mathrm{X}$ & & & & & & \\
\hline & Silicula rouchi Lamy, 1910 & & & $?$ & & $X$ & $\mathrm{X}$ & * \\
\hline \multirow[t]{7}{*}{ Limopsidae } & Limopsis hirtella Mabille and Rochebrune, 1889 & $\mathrm{X}$ & $X$ & & & & & \\
\hline & Limopsis jousseaumi (Mabille and Rochebrune, 1889) & $\mathrm{X}$ & & & & & & \\
\hline & $\begin{array}{l}\text { Limopsis lillei Smith, } 1915 \\
\text { Limopsis } \mathrm{cf} \text { marionensis Smith, } 1885\end{array}$ & & & $X$ & $\mathrm{X}$ & * & * & $*$ \\
\hline & Limopsis scotiana Dell, 1964 & & & $\mathrm{X}$ & $\mathrm{X}^{1}$ & $\mathrm{X}$ & $\mathrm{X}$ & \\
\hline & Limopsis sp. & & & & $\mathrm{X}$ & & & \\
\hline & Lissarca cf. miliaris (Philippi, 1845) & $\mathrm{X}$ & * & * & & * & $\mathrm{X}$ & $\mathrm{X}$ \\
\hline & Lissarca notorcadensis Melvill and Standen,1907 & & $\mathrm{X}^{1}$ & $\mathrm{X}$ & $\mathrm{X}$ & $\mathrm{X}$ & $\mathrm{X}$ & $\mathrm{X}$ \\
\hline \multirow{16}{*}{ Philobryidae } & Adacnarca limopsoides (Thiele, 1912) & & & & & $?$ & * & * \\
\hline & Adacnarca nitens Pelseneer, 1903 & & & $*$ & $X$ & $\mathrm{X}$ & $\mathrm{X}$ & * \\
\hline & Adacnarca n. sp. & & & $\mathrm{X}^{1}$ & & & & \\
\hline & Philobrya atlantica Dall, 1895 & $*$ & $*$ & $*$ & & & & \\
\hline & Philobrya capillata Dell, 1964 & & $*$ & & & & & $*$ \\
\hline & Philobrya crispa Linse, 2002 & $\mathrm{X}$ & & & & & & \\
\hline & Philobrya cf. kerguelensis Smith, 1885 & & & $*$ & & & & \\
\hline & Philobrya magellanica (Stempell, 1899) & $\mathrm{X}$ & & & & & & \\
\hline & Philobrya multistriata Lamy, 1908 & $?$ & $\mathrm{X}$ & & & & & \\
\hline & Philobrya olstadi (Soot-Ryen, 1951) & & & & & * & * & $\mathrm{X}^{1}$ \\
\hline & Philobrya quadrata (Pfeffer in Martens and Pfeffer, 1886) & ? & & $\mathrm{X}$ & & $*$ & & ? \\
\hline & Philobrya sublaevis Pelseneer, 1903 & & & $\mathrm{X}$ & $\mathrm{X}$ & $X$ & $\mathrm{X}$ & * \\
\hline & Philobrya wandelensis Lamy, 1906 & & $?$ & $\mathrm{X}$ & $\mathrm{X}^{1}$ & * & * & * \\
\hline & Philobrya n. sp. 1 & & $X^{1}$ & & & & & \\
\hline & Philobrya n. sp. 2 & & $X^{1}$ & & & & & \\
\hline & Philobrya n. sp. 3 & $\mathrm{X}^{1}$ & & & & & & \\
\hline \multirow{5}{*}{ Mytilidae } & Aulacomya atra (Molina, 1782) & $\mathrm{X}$ & * & & & & & \\
\hline & Crenella magellanica Linse, 2002 & $\mathrm{X}$ & $\mathrm{X}^{1}$ & & & & & \\
\hline & Dacrydium cf. albidum Pelseneer, 1903 & & & & $\mathrm{X}^{1}$ & & $*$ & $*$ \\
\hline & Mytilus chilensis Hupé, 1854 & $\mathrm{X}$ & * & $?$ & & & & \\
\hline & Perumytilus purpuratus (Lamarck, 1819) & $\mathrm{X}$ & $\mathrm{X}^{1}$ & & & & & \\
\hline \multirow[t]{6}{*}{ Limidae } & Acesta patagonica Dall, 1902 & $\mathrm{X}$ & & & & & & \\
\hline & Limatula hodgsoni (Smith, 1907) & & & $\mathrm{X}$ & $\mathrm{X}$ & $X$ & $\mathrm{X}$ & $*$ \\
\hline & Limatula ovalis (Thiele, 1912) & & & & & & * & $X$ \\
\hline & Limatula pygmaea (Philippi, 1845) & $\mathrm{X}$ & $\mathrm{X}$ & ? & & & & \\
\hline & Limatula simillima Thiele, 1912 & & & & & * & & * \\
\hline & Limatula n. sp. & $X^{1}$ & $\mathrm{X}^{1}$ & & & & & \\
\hline \multirow[t]{4}{*}{ Pectinidae } & Adamussium colbecki (Smith, 1902) & & & & $*$ & $\mathrm{X}$ & $*$ & * \\
\hline & Chlamys tehuelchus (d’Orbigny, 1846) & $\mathrm{X}$ & & & & & & \\
\hline & Semipallium natans (Philippi, 1845) & $\mathrm{X}$ & & & & & & \\
\hline & Zygochlamys patagonica (King and Broderip, 1832) & $\mathrm{X}$ & $\mathrm{X}$ & & & & & \\
\hline Propeamussiidae & Cyclopecten falklandicus Dell, 1964 & $*$ & $\mathrm{X}$ & & & & & \\
\hline & Cyclopecten gaussianus (Thiele, 1912) & & & & & & & * \\
\hline & Cyclopecten multistriatus Linse, 2002 & $\mathrm{X}$ & & & & & & \\
\hline & Cyclopecten pteriola (Melvill and Standen, 1907) & & & & & * & & $?$ \\
\hline & Cyclopecten n. sp. 1 & & $\mathrm{X}^{1}$ & & & & & \\
\hline & Cyclopecten n. sp. 2 & & $\mathrm{X}^{1}$ & & & & & \\
\hline & Cyclopecten n. sp. 3 & & & & $\mathrm{X}^{1}$ & & & \\
\hline & Cyclopecten n. sp. 4 & & & $\mathrm{X}^{1}$ & & & & \\
\hline & Cyclopecten n. sp. 5 & & & $\mathrm{X}^{1}$ & & & & \\
\hline
\end{tabular}


TABLE 1 (Cont.). - List of bivalve species and their geographic distribution. X: this study; $\mathrm{X}^{1}$ : new records from this study; *: literature records; ?: presence uncertain; P, Patagonia; M/F, Malvinas / Falkland Is.; SG, South Georgia; SS, South Sandwich Is.; SO, South Orkney Is.; SSH South Shetland Is.;WS, Antarctic Weddell sector.

\begin{tabular}{|c|c|c|c|c|c|c|c|c|}
\hline Family & Species & $\mathrm{P}$ & $\mathrm{M} / \mathrm{F}$ & SG & SS & SO & SSH & WS \\
\hline Lucinidae & $\begin{array}{l}\text { Epicodakia falklandica Dell, } 1964 \\
\text { Lucinoma lamellata (Smith, 1881) }\end{array}$ & $\begin{array}{l}X \\
X\end{array}$ & * & $\mathrm{X}^{1}$ & & $\mathrm{X}^{1}$ & & \\
\hline \multirow[t]{7}{*}{ Thyasiridae } & Genaxinus (?) debilis (Thiele, 1912) & $?$ & $?$ & $\mathrm{X}$ & $\mathrm{X}$ & $\mathrm{X}$ & $\mathrm{X}$ & $*$ \\
\hline & Thyasira bongraini (Lamy, 1910) & & & & & $\underset{0}{X}$ & $*$ & $*$ \\
\hline & $\begin{array}{l}\text { Thyasira falklandica (Smith, 1885) } \\
\text { Thyasira fuegiensis (Dall. 1889) }\end{array}$ & $\mathrm{X}$ & $X$ & $?$ & & & $?$ & \\
\hline & Thyasira magellanica Dall, 1901 & $\mathrm{X}$ & & & & & & \\
\hline & Thyasira $\mathrm{n}$. sp. 1 & $\mathrm{X}^{1}$ & & & & & & \\
\hline & Thyasira n. sp. 2 & & & $\mathrm{X}^{1}$ & & & $\mathrm{X}^{1}$ & \\
\hline & Thyasira n. sp. 3 & & & $\mathrm{X}^{1}$ & & $\mathrm{X}^{1}$ & & \\
\hline \multirow[t]{2}{*}{ Astartidae } & Astarte longirostris d’Orbigny, 1846 & $\mathrm{X}$ & $\mathrm{X}$ & $*$ & & & & \\
\hline & Astarte antarctica Thiele, 1912 & & & & & & $X$ & $*$ \\
\hline \multirow[t]{6}{*}{ Carditidae } & Carditella naviformis (Reeve, 1834) & $X$ & $*$ & & & & & \\
\hline & Carditella pallida (Smith, 1881) & $\mathrm{X}$ & & & & & & \\
\hline & Cyclocardia astartoides (Martens, 1878) & $?$ & & $\mathrm{X}$ & $\mathrm{X}$ & $\mathrm{X}$ & * & * \\
\hline & Cyclocardia compressa Reeve, 1843 & $\mathrm{X}$ & $\mathrm{X}^{1}$ & & & & & \\
\hline & Cyclocardia thouarsi (d’Orbigny, 1846) & * & $\mathrm{X}$ & & & & & \\
\hline & Venericardia velutina (Smith, 1881) & $\mathrm{X}$ & * & & & & & \\
\hline \multirow{3}{*}{ Condylocardiidae } & Carditopsis flabellum (Reeve, 1843) & * & $*$ & & & & & \\
\hline & Benthocardiella $\mathrm{n} . \mathrm{sp} .1$ & $\mathrm{X}^{1}$ & & & & & & \\
\hline & Benthocardiella n. sp. 2 & $\mathrm{X}^{1}$ & & & & & & \\
\hline \multirow[t]{15}{*}{ Lasaeidae } & Kellia cf. magellanica Smith, 1881 & $\mathrm{X}$ & $*$ & & & & & \\
\hline & Kellia simulans Smith, 1907 & & & & & & * & * \\
\hline & $\begin{array}{l}\text { Kellia } \text { sp. } 1 \\
\text { Kellia } \text { sp. } 2\end{array}$ & $\mathrm{X}$ & & $\mathrm{X}$ & & & & \\
\hline & Kellia sp. 3 & & & & & $\mathrm{X}$ & & \\
\hline & Lasaea adansoni (Gmelin, 1791) [following Coan et al., 2000] & $\mathrm{X}$ & $\mathrm{X}$ & $*$ & & * & & \\
\hline & Montacuta (?) nimrodiana (Hedley, 1911) & & & $\mathrm{X}^{1}$ & & $\mathrm{X}^{1}$ & $*$ & * \\
\hline & Mysella (?) arthuri (Cooper and Preston, 1910) & & $X$ & & & & & \\
\hline & Mysella (?) miniuscula (Pfeffer in Martens and Pfeffer, 1886 & & & $\mathrm{X}$ & * & $*$ & * & * \\
\hline & Pseudokellya cardiformis (Smith, 1885) & & $*$ & $\mathrm{X}$ & * & & * & $*$ \\
\hline & Pseudokellya georgiana Dell, 1964 & & & $\mathrm{X}$ & & & & \\
\hline & Pseudokellya gradata Thiele, 1912 & & & & & $*$ & $*$ & * \\
\hline & Pseudokellya inexpectata Dell, 1964 & & & $\mathrm{X}$ & & $*$ & & \\
\hline & Rochefortia charcoti (Lamy, 1906) & $?$ & & $*$ & & * & $\mathrm{X}$ & $*$ \\
\hline & Rochefortia mabillei Dall, 1908 & $\mathrm{X}$ & $\mathrm{X}^{1}$ & & & & & \\
\hline & Rochefortia rochebrunei Dall, 1908 & $\mathrm{X}$ & & & & & & \\
\hline \multirow{2}{*}{ Galeommatoidea } & Waldo parasiticus (Dall, 1876) & $\mathrm{X}$ & & $\mathrm{X}$ & & $\mathrm{X}^{1}$ & * & \\
\hline & Waldo trapezialis Zelaya and Ituarte, 2002 & & & $\mathrm{X}$ & & $\mathrm{X}^{1}$ & & \\
\hline \multirow[t]{19}{*}{ Cyamiidae } & Cyamium antarcticum Philippi, 1845 & $\mathrm{X}$ & $\mathrm{X}$ & & & & & \\
\hline & Cyamium falklandicum Melvill and Standen, 1898 & & * & & & & & \\
\hline & Cyamium iridescens Cooper and Preston, 1910 & & $*$ & & & & & \\
\hline & Cyamium willii Pfeffer in Martens and Pfeffer, 1886 & & & $*$ & & & & \\
\hline & Cyamiocardium crassilabrum Dell, 1964 & $\mathrm{X}$ & $*$ & & & & & \\
\hline & Cyamiocardium dahli Soot-Ryen, 1957 & $\mathrm{X}$ & & & & & & \\
\hline & Cyamiocardium denticulatum (Smith, 1907) & $?$ & $?$ & & & $\mathrm{X}^{1}$ & $\mathrm{X}$ & * \\
\hline & Cyamiocardium n. sp. & & & $\mathrm{X}^{1}$ & & & & \\
\hline & Cyamiomactra laminifera (Lamy, 1906) & & $?$ & $\mathrm{X}$ & * & $*$ & $*$ & $*$ \\
\hline & Gaimardia adamsorium Osorio and Arnaud, 1984 & & * & & & & & \\
\hline & Gaimardia bennetti (Preston, 1913) & $\mathrm{X}^{1}$ & $\mathrm{X}$ & & & & & \\
\hline & Gaimardia trapesina (Lamarck, 1819) & $\mathrm{X}$ & $\mathrm{X}$ & $\mathrm{X}$ & & & & \\
\hline & Gaimardia sp. & $\mathrm{X}$ & & & & & & \\
\hline & Kidderia bicolor (Martens, 1885) & & & $*$ & & & & \\
\hline & Kidderia pusilla (Gould, 1845) & $\mathrm{X}$ & $*$ & & & & & \\
\hline & Kidderia subquadrata (Pelseneer, 1903) & & & & & & $\mathrm{X}$ & $\mathrm{X}$ \\
\hline & Kidderia sp. 1 & * & & & & & & \\
\hline & Kidderia sp. 2 & & $\mathrm{X}$ & & & & & \\
\hline & Ptychocardia vanhoeffeni Thiele, 1912 & & & & & & & $*$ \\
\hline \multirow{10}{*}{ Neoleptonidae } & Neolepton amatoi Zelaya and Ituarte, 2004 & * & & & & & & \\
\hline & Neolepton cobbi (Cooper and Preston, 1910) & $\mathrm{X}$ & $\mathrm{X}$ & & & & & \\
\hline & Neolepton concentricum (Preston, 1912) & $\mathrm{X}^{1}$ & $*$ & & & & & \\
\hline & Neolepton falklandicum Dell, 1964 & $\mathrm{X}^{1}$ & $\mathrm{X}$ & & & & & \\
\hline & Neolepton georgianum Zelaya and Ituarte, 2003 & & & $*$ & & & & \\
\hline & Neolepton holmbergi Zelaya and Ituarte, 2003 & & & * & & & & \\
\hline & Neolepton hupei Soot-Ryen, 1957 & $\mathrm{X}$ & $\mathrm{X}$ & & & & & \\
\hline & Neolepton yagan Zelaya and Ituarte, 2004 & $*$ & & & & & & \\
\hline & Neolepton n. sp. & $\mathrm{X}^{1}$ & & & & & & \\
\hline & Puyseguria $\mathrm{n}$. sp. & $\mathrm{X}^{1}$ & & & & & & \\
\hline Cardiidae & Trachycardium delicatulum (Smith, 1915) & & $*$ & & & & & \\
\hline
\end{tabular}


TABLE 1 (Cont.). - List of bivalve species and their geographic distribution. X: this study; $\mathrm{X}^{1}$ : new records from this study; *: literature records; ?: presence uncertain; P, Patagonia; M/F, Malvinas / Falkland Is.; SG, South Georgia; SS, South Sandwich Is.; SO, South Orkney Is.; SSH South Shetland Is.;WS, Antarctic Weddell sector.

\begin{tabular}{|c|c|c|c|c|c|c|c|c|}
\hline Family & Species & $\mathrm{P}$ & $\mathrm{M} / \mathrm{F}$ & SG & SS & $\mathrm{SO}$ & $\mathrm{SSH}$ & WS \\
\hline \multirow[t]{4}{*}{ Veneridae } & Eurhomalea exalbida (Dillwyn, 1817) & $\mathrm{X}$ & $*$ & & & & & \\
\hline & Gomphina foveolata (Cooper and Preston, 1910) & $\mathrm{X}$ & $*$ & & & & & \\
\hline & Protothaca antiqua (King and Broderip, 1832) & $X$ & & & & & & \\
\hline & Tawera gayi (Hupé in Gay, 1854) & $\mathrm{X}$ & $?$ & & & & & \\
\hline Petricolidae & Petricola dactylus G. B. Sowerby I, 1823 [sensu & 7]X & & & & & & \\
\hline \multirow[t]{2}{*}{ Tellinidae } & Macoma georgiana Dell, 1964 & & & $*$ & & & & \\
\hline & Macoma inornata (Hanley, 1844) & $\mathrm{X}$ & $*$ & & & & & \\
\hline Pharidae & Ensis macha Molina, 1789 & $\mathrm{X}$ & $\mathrm{X}$ & & & & & \\
\hline \multirow[t]{2}{*}{ Mactridae } & Darina solenoides (King and Broderip, 1832) & $\mathrm{X}$ & $*$ & & & & & \\
\hline & Mulinia (?) edulis (King and Broderip, 1832) & $\mathrm{X}$ & & & & & & \\
\hline \multirow[t]{2}{*}{ Myidae } & Mya antarctica Melvill and Standen, 1914 & $\mathrm{X}^{1}$ & $*$ & & & & & \\
\hline & Sphenia hatcheri Pilsbry, 1899 & $\mathrm{X}$ & & & & & & \\
\hline \multirow[t]{2}{*}{ Hiatellidae } & Hiatella meridionalis d' Orbigny, 1846 & $\mathrm{X}$ & $*$ & $\mathrm{X}$ & & & & \\
\hline & Hiatella sp. & $\mathrm{X}$ & $\mathrm{X}$ & & $*$ & & & \\
\hline Teredinidae & Bankia martensi Stempell, 1899 & $*$ & & & & & & \\
\hline Pandoridae & Pandora patagonica (Dall, 1915) & $\mathrm{X}$ & & & & & & \\
\hline \multirow[t]{2}{*}{ Lyonsiidae } & Lyonsia cf. arcaeformis Martens, 1885 & $\mathrm{X}^{1}$ & & $\mathrm{X}$ & $\mathrm{X}^{1}$ & $\mathrm{X}$ & $*$ & $*$ \\
\hline & Lyonsia fretalis Dall, 1915 & $*$ & $*$ & & & & & \\
\hline \multirow[t]{2}{*}{ Thraciidae } & Thracia meridionalis Smith, 1885 & $?$ & $\mathrm{X}$ & $\mathrm{X}$ & $*$ & $\mathrm{X}$ & $\mathrm{X}$ & $*$ \\
\hline & Thracia sp. & $\dot{X}$ & & & & & & \\
\hline Laternulidae & Laternula elliptica (King and Broderip, 1832) & & & $\mathrm{X}$ & $*$ & $*$ & $\mathrm{X}$ & $*$ \\
\hline \multirow[t]{6}{*}{ Cuspidariidae } & Cardiomya simillima Smith, 1915 & $\mathrm{X}$ & $*$ & & & & & \\
\hline & Cuspidaria concentrica Thiele, 1912 & & $\mathrm{X}^{1}$ & $\mathrm{X}^{1}$ & & & & \\
\hline & Cuspidaria minima (Egorova, 1993) & & & & & $*$ & $\mathrm{X}^{1}$ & \\
\hline & Cuspidaria tenella Smith, 1907 & $*$ & $*$ & $\mathrm{X}$ & $*$ & $*$ & $*$ & $*$ \\
\hline & Cuspidaria sp.1 & $\mathrm{X}$ & $\mathrm{X}$ & $\mathrm{X}$ & $\mathrm{X}$ & $\mathrm{X}$ & $\mathrm{X}$ & \\
\hline & Cuspidaria sp. 2 & & & $\mathrm{X}$ & & & & \\
\hline Verticordiidae & Lyonsiella radiata Dall, 1889 & $*$ & & & & & & \\
\hline Poromyidae & Poromya adelaidis (Hedley, 1916) & & $\mathrm{X}$ & $\mathrm{X}^{1}$ & $\mathrm{X}^{1}$ & $\mathrm{X}^{1}$ & $\mathrm{X}$ & \\
\hline \multicolumn{2}{|c|}{ Total number of species } & 93 & 67 & 49 & 25 & 43 & 42 & 41 \\
\hline
\end{tabular}

America, between Peninsula Valdés $\left(\sim 43^{\circ} \mathrm{S}\right)$ in the Atlantic Ocean, and $42^{\circ} \mathrm{S}$ in the Pacific Ocean. The reference to the Islas Malvinas/Falkland Islands also includes the Burdwood Bank.

This study was restricted to the bivalve faunas from shelf waters. In the case of the South Sandwich Islands (where a shelf does not exist) the $600 \mathrm{~m}$ isobath was considered as the depth limit. Those species characteristic of Argentine and Peruvian Provinces that occasionally reach the northern limit of the Magellan region were not considered in this study.

The high level classification of bivalves follows Coan et al. (2000). "Endemics" refers to species only known from one of the archipelagos or any of the above mentioned areas (e.g. Patagonia or the Antarctic Weddell sector), which are mentioned in each particular case.

\section{Analysis of similarity}

Degrees of faunistic affinity among the areas were evaluated by using the Simpson similarity coefficient (SI). This coefficient moderates the bias caused by different sampling efforts (Cheetham and Hazel, 1969). The percentage of similarity, referred to as "similarity" in the text, was determined as SI x 100.

\section{RESULTS}

Table 1 lists the 170 species recognised as present in the study area and shows their geographic distribution. Specimens of 147 species were examined during this study, 18 of which are still undescribed. In addition, another 23 species known from literature records were regarded to be distinct species with a reasonable certainty. Seventy-three of the 170 listed species were present in the Scotia Arc islands, while the remaining 97 species only occurred in Patagonia, Islas Malvinas/Falkland Islands or the Antarctic Weddell sector. The South Georgia, South Orkney and South Shetland islands accounted for a similar number of species $(49,43$ and 42 species respectively), a species richness sim- 
TABLE 2. - Simpson similarity coefficient values (SI) for the analysed areas.

\begin{tabular}{|c|c|c|c|c|c|c|c|}
\hline & Patagonia & Malvinas/Falkland & South Georgia & South Sandwich & South Orkney & South Shetland & Weddell Sector \\
\hline Patagonia & 1 & & & & & & \\
\hline Malvinas / Falkland & 0.70 & 1 & & & & & \\
\hline South Georgia & 0.24 & 0.29 & 1 & & & & \\
\hline South Sandwich & 0.16 & 0.32 & 0.68 & 1 & & & \\
\hline South Orkney & 0.18 & 0.21 & 0.67 & 0.80 & 1 & & \\
\hline South Shetland & 0.12 & 0.21 & 0.57 & 0.88 & 0.81 & 1 & \\
\hline Weddell Sector & 0.10 & 0.17 & 0.49 & 0.72 & 0.71 & 0.85 & 1 \\
\hline
\end{tabular}

ilar to that of the Antarctic Weddell sector (41 species) but clearly lower than that of Patagonia and the Islas Malvinas/Falkland Islands (93 and 67 species respectively). The lowest number of species was found off the South Sandwich Islands, where only 25 species of bivalves were recognised.

The South Sandwich Islands showed a high faunistic similarity to the South Shetland Islands (88\%) and a lower similarity to the South Orkney Islands (80\%) and South Georgia (68\%) (Table 2). South Georgia showed a moderately high similarity to the South Orkney Islands (67\%) and the South Shetland Islands (51\%). Similarity values between the South Orkney Islands and the South Shetland Islands were high $(81 \%)$ (Table 2). Comparisons made between each component of the Scotia Arc islands and the remaining areas showed high similarity to the Antarctic Weddell sector (49 to 85\%, depending on the archipelago) and low similarity to Patagonia and the Islas Malvinas/Falkland Islands (12 to 29\%) (Table 2).

Of the 73 species from the Scotia Arc islands, 26 (36\%) were endemic to the Scotia Sea, 28 were shared with the Antarctic Weddell sector and 11 were shared with Patagonia or the Islas Malvinas/Falkland Islands; the remaining 8 species were widespread, and present in the Scotia Arc islands, the Islas Malvinas/Falkland Islands, Patagonia and the Antarctic Weddell sector. The contribution of the "endemic" species to the total species number of each archipelago was: Islas Malvinas/Falkland Islands, 12 species (18\%); South Georgia, 14 species (29\%); South Sandwich Islands, 2 species (8\%); South Orkney Islands, 2 species (7\%); and South Shetland Islands, 0 species. At a larger regional scale, Patagonia showed 43 species ( $446 \%$ of the total) that were not found in the Scotia Arc islands or the Antarctic Weddell sector, and the Antarctic Weddell sector contributed 4 species $(10 \%)$ that were not found in the Scotia Arc islands or Patagonia.

A genus-level analysis showed that the generic richness in South Georgia (35 genera) was greatest among the Scotia Arc islands and the Antarctic Weddell sector (Table 3). However, this diversity is smaller than values from Patagonia (61 genera) and the Islas Malvinas/Falkland Islands (46 genera).

Of the 73 genera recognised in this study, 33 occurred only in Patagonia and the Islas Malvinas/Falkland Islands; 5 genera were present only in Patagonia, the Islas Malvinas/Falkland Islands and South Georgia, and a further 5 genera also extended to other islands of the Scotia Arc. Eight genera were shared only by the Scotia Arc islands and the Antarctic Weddell sector and one genus (Ptychocardia) was found only in the Antarctic Weddell sector (Table 3). The remaining 21 genera were widely spread and represented in the Scotia Arc islands, the Antarctic Weddell sector and Patagonia. No endemic genera were found for the Scotia Arc islands.

The genus Philobrya accounted for the largest number of species (13), followed by Neolepton (9), Cyclopecten (9), Yoldiella (7) and Thyasira (7) . Limopsis and Kellia were represented by six and five species each, and the remaining genera by a lower number of species, usually one or two.

\section{DISCUSSION}

The present study revealed the existence of a widely diversified bivalve fauna in the Scotia Arc islands and adjacent waters, reporting 18 still undescribed species and providing new records for 51 species. The total number of species reported in this study for the Scotia Arc islands (73) is higher than the numbers previously reported by Carcelles (1953) and Powell (1960) for the same area (45 and 35 species respectively). This difference clearly reflects the increase in the knowledge of bivalve diversity in the last 40 years. The same occurs in the Weddell Sea, where several recent specific studies also resulted in a considerable increase in the total number of species for the area. Conversely, the number of species reported here for the Magellan region 
TABLE 3. - Geographic distribution of bivalve genera.

\begin{tabular}{|c|c|c|c|c|c|c|c|}
\hline GENERA & Patagonia & $\begin{array}{l}\text { Malvinas/ } \\
\text { Falkland Is. }\end{array}$ & South Georgia & $\begin{array}{c}\text { South } \\
\text { Sandwich Is. }\end{array}$ & South Orkney Is. & $\begin{array}{c}\text { South } \\
\text { Shetland Is. }\end{array}$ & $\begin{array}{c}\text { Antarctic } \\
\text { Weddell sector }\end{array}$ \\
\hline Acesta & $\mathrm{x}$ & & & & & & \\
\hline Acharax & $\mathrm{x}$ & & & & & & \\
\hline Adacnarca & & & $\mathrm{x}$ & $\mathrm{x}$ & $\mathrm{x}$ & $\mathrm{x}$ & $\mathrm{x}$ \\
\hline Adamussium & & & & $\mathrm{x}$ & $\mathrm{x}$ & $\mathrm{x}$ & $\mathrm{x}$ \\
\hline Astarte & $\mathrm{x}$ & $\mathrm{x}$ & $\mathrm{x}$ & & & $\mathrm{x}$ & $\mathrm{x}$ \\
\hline Aulacomya & $\mathrm{x}$ & $\mathrm{x}$ & & & & & \\
\hline Bankia & $\mathrm{x}$ & & & & & & \\
\hline Benthocardiella & $\mathrm{x}$ & & & & & & \\
\hline Carditella & $\mathrm{x}$ & $\mathrm{x}$ & & & & & \\
\hline Cardiomya & $\mathrm{x}$ & $\mathrm{x}$ & & & & & \\
\hline Carditopsis & $\mathrm{x}$ & $\mathrm{x}$ & & & & & \\
\hline Chlamys & $\mathrm{x}$ & & & & & & \\
\hline Crenella & $\mathrm{x}$ & $\mathrm{x}$ & & & & & \\
\hline Cuspidaria & $\mathrm{x}$ & $\mathrm{x}$ & $\mathrm{x}$ & $\mathrm{x}$ & $\mathrm{x}$ & $\mathrm{x}$ & $\mathrm{x}$ \\
\hline Cyamiocardium & $\mathrm{x}$ & $\mathrm{x}$ & $\mathrm{x}$ & & $\mathrm{x}$ & $\mathrm{x}$ & $\mathrm{x}$ \\
\hline Cyamiomactra & & ? & $\mathrm{x}$ & $\mathrm{x}$ & $\mathrm{x}$ & $\mathrm{x}$ & $\mathrm{x}$ \\
\hline Cуатіum & $\mathrm{x}$ & $\mathrm{x}$ & $\mathrm{x}$ & & & & \\
\hline Cyclocardia & $\mathrm{x}$ & $\mathrm{x}$ & $\mathrm{x}$ & $\mathrm{x}$ & $\mathrm{x}$ & $\mathrm{x}$ & $\mathrm{x}$ \\
\hline Cyclopecten & $\mathrm{x}$ & $\mathrm{x}$ & $\mathrm{x}$ & $\mathrm{x}$ & $\mathrm{x}$ & & $\mathrm{x}$ \\
\hline Dacridium & & & & $\mathrm{x}$ & & $\mathrm{x}$ & $\mathrm{x}$ \\
\hline Darina & $\mathrm{x}$ & $\mathrm{x}$ & & & & & \\
\hline Enписиla & $\mathrm{x}$ & ? & $\mathrm{x}$ & & & & \\
\hline Ensis & $\mathrm{x}$ & $\mathrm{x}$ & & & & & \\
\hline Epicodakia & $\mathrm{x}$ & $\mathrm{x}$ & $\mathrm{x}$ & & $\mathrm{x}$ & & \\
\hline Eurhomalea & $\hat{x}$ & $\mathrm{x}$ & $\Lambda^{\prime}$ & & $\Lambda$ & & \\
\hline Gaimardia & $\mathrm{x}$ & $\mathrm{x}$ & $\mathrm{x}$ & & & & \\
\hline Genaxinus & ? & ? & $\mathrm{x}$ & $\mathrm{x}$ & $\mathrm{x}$ & $\mathrm{x}$ & $\mathrm{x}$ \\
\hline Gomphina & $\mathrm{x}$ & $\mathrm{x}$ & & & & & \\
\hline Hiatella & $\mathrm{x}$ & $\mathrm{x}$ & $\mathrm{x}$ & $\mathrm{x}$ & & & \\
\hline Kellia & $\mathrm{x}$ & $\mathrm{x}$ & $\mathrm{x}$ & & $\mathrm{x}$ & $\mathrm{x}$ & $\mathrm{x}$ \\
\hline Kidderia & $\mathrm{x}$ & $\mathrm{x}$ & $\mathrm{x}$ & & & $\mathrm{x}$ & $\mathrm{x}$ \\
\hline Lasaea & $\mathrm{x}$ & $\mathrm{x}$ & $\mathrm{x}$ & & $\mathrm{x}$ & & \\
\hline Laternula & & & $\mathrm{x}$ & $\mathrm{x}$ & $\mathrm{x}$ & $\mathrm{x}$ & $\mathrm{x}$ \\
\hline Limatula & $\mathrm{x}$ & $\mathrm{x}$ & $\mathrm{x}$ & $\mathrm{x}$ & $\mathrm{x}$ & $\mathrm{x}$ & $\mathrm{x}$ \\
\hline Limopsis & $\mathrm{x}$ & $\mathrm{x}$ & $\mathrm{x}$ & $\mathrm{x}$ & $\mathrm{x}$ & $\mathrm{x}$ & $\mathrm{x}$ \\
\hline Lissarca & $\mathrm{x}$ & $\mathrm{x}$ & $\mathrm{x}$ & $\mathrm{x}$ & $\mathrm{x}$ & $\mathrm{x}$ & $\mathrm{x}$ \\
\hline Lucinoma & $\mathrm{x}$ & $\mathrm{x}$ & & & & & \\
\hline Lyonsia & $\mathrm{x}$ & $\mathrm{x}$ & $\mathrm{x}$ & $\mathrm{x}$ & $\mathrm{x}$ & $\mathrm{x}$ & $\mathrm{x}$ \\
\hline Lyonsiella & $\mathrm{x}$ & & & & & & \\
\hline Macoma & $\mathrm{x}$ & $\mathrm{x}$ & $\mathrm{x}$ & & & & \\
\hline Malletia & $\mathrm{x}$ & $\mathrm{x}$ & & & & & \\
\hline "Montacuta" & & & $\mathrm{x}$ & & $\mathrm{x}$ & $\mathrm{x}$ & $\mathrm{x}$ \\
\hline "Mulinia" & $\mathrm{x}$ & & & & & & \\
\hline Mya & $\mathrm{x}$ & $\mathrm{x}$ & & & & & \\
\hline "Mysella" & & $\mathrm{x}$ & $\mathrm{x}$ & $\mathrm{x}$ & $\mathrm{x}$ & $\mathrm{x}$ & $\mathrm{x}$ \\
\hline Mytilus & $\mathrm{x}$ & $\mathrm{x}$ & $?$ & & & & \\
\hline Neolepton & $\mathrm{x}$ & $\mathrm{x}$ & $\mathrm{x}$ & & & & \\
\hline Nucula & $\mathrm{x}$ & $\mathrm{x}$ & & & ? & & ? \\
\hline Nuculana & $\mathrm{x}$ & $\mathrm{x}$ & & & $\mathrm{x}$ & $\mathrm{x}$ & $\mathrm{x}$ \\
\hline Pandora & $\mathrm{x}$ & & & & & & \\
\hline Perumytilus & $\mathrm{x}$ & $\mathrm{x}$ & & & & & \\
\hline Petricola & $\mathrm{x}$ & & & & & & \\
\hline Philobrya & $\mathrm{x}$ & $\mathrm{x}$ & $\mathrm{x}$ & $\mathrm{x}$ & $\mathrm{x}$ & $\mathrm{x}$ & $\mathrm{x}$ \\
\hline Poromya & & $\mathrm{x}$ & $\mathrm{x}$ & $\mathrm{x}$ & $\mathrm{x}$ & $\mathrm{x}$ & \\
\hline Propeleda & $\mathrm{x}$ & & $\mathrm{x}$ & & $\mathrm{x}$ & $\mathrm{x}$ & $\mathrm{x}$ \\
\hline Protothaca & $\mathrm{x}$ & & & & & & \\
\hline Pseudokellya & & $\mathrm{x}$ & $\mathrm{x}$ & $\mathrm{x}$ & $\mathrm{x}$ & $\mathrm{x}$ & $\mathrm{x}$ \\
\hline Ptychocardia & & & & & & & $\mathrm{x}$ \\
\hline Puyseguria & $\mathrm{x}$ & & & & & & \\
\hline Rochefortia & $\mathrm{x}$ & $\mathrm{x}$ & $\mathrm{x}$ & & $\mathrm{x}$ & $\mathrm{x}$ & $\mathrm{x}$ \\
\hline Semipallium & $\mathrm{x}$ & & & & & & \\
\hline Silicula & $\mathrm{x}$ & & $\mathrm{x}$ & & $\mathrm{x}$ & $\mathrm{x}$ & $\mathrm{x}$ \\
\hline Sphenia & $\mathrm{x}$ & & & & & & \\
\hline Tawera & $\mathrm{x}$ & ? & & & & & \\
\hline Thracia & $\mathrm{x}$ & $\mathrm{x}$ & $\mathrm{x}$ & $\mathrm{x}$ & $\mathrm{x}$ & $\mathrm{x}$ & $\mathrm{x}$ \\
\hline Thyasira & $\mathrm{x}$ & $\mathrm{x}$ & $\mathrm{x}$ & & $\mathrm{x}$ & $\mathrm{x}$ & $\mathrm{x}$ \\
\hline Tindaria & $\mathrm{x}$ & & & & & & \\
\hline Trachycardium & & $\mathrm{x}$ & & & & & \\
\hline Venericardia & $\mathrm{x}$ & $\mathrm{x}$ & & & & & \\
\hline Waldo & $\mathrm{x}$ & & $\mathrm{x}$ & & $\mathrm{x}$ & $\mathrm{x}$ & \\
\hline Yoldia & $\hat{x}$ & $\mathrm{x}$ & $\hat{x}$ & $\mathrm{x}$ & $\mathrm{x}$ & $\mathrm{x}$ & $\mathrm{x}$ \\
\hline Yoldiella & $\mathrm{x}$ & $\mathrm{x}$ & & $\mathrm{x}$ & $\mathrm{x}$ & $\mathrm{x}$ & $\mathrm{x}$ \\
\hline Zygochlamys & $\mathrm{x}$ & $\mathrm{x}$ & & & & & \\
\hline Total number of genera & 61 & 46 & 35 & 21 & 30 & 29 & 29 \\
\hline
\end{tabular}


was lower than those listed by Carcelles (1950), Carcelles and Williamson (1951) and Linse (1999), who included several names which are actually synonymous or have been erroneously reported for the area (Zelaya, unpubl. inf.). The list of species given by Linse (1999) also includes deep-water species, which are not the focus of the present paper.

The values of faunistic similarity among components of the Scotia Arc islands ranged from 57 to $88 \%$, accounting for a relatively homogeneous species composition of the bivalve fauna. The highest similarity values were found among components of the southern branch of the Scotia Arc, i.e. in the couples South Sandwich-South Orkneys, South Sandwich-South Shetland and South OrkneysSouth Shetlands. The lowest similarity was found when comparing the northern and southern branches of the Scotia Arc (i.e. the couples South Georgia - South Shetland Islands and South Georgia - South Orkney Islands). Although species richness was similar in these archipelagos, the composition of their assemblages was found to be somewhat different. This fact originates from the high number of endemic species occurring in South Georgia (14 species, $29 \%$ of the total). Moreover, South Georgia has a greater number of Magellanic components than the South Orkney and South Shetland islands, whose faunas are of predominantly Antarctic origin.

The biogeographic position of South Georgia has been the focus of controversial opinions. Based on evidence coming from different invertebrate taxa, authors have proposed its placement either in the Antarctic or Magellan regions (Arnaud, 1964; Clarke, 1996; Hasting, 1943; Hedgpeth, 1969; Linse, 1997; Winkler, 1994; Zelaya, 2000). South Georgia bivalve assemblages included representatives from both the Magellan and Antarctic faunas. A similar mixed origin was previously reported for other invertebrate groups, such as Cumacea (Mühlenhardt-Siegel, 1999), Sipuncula (Saiz-Salinas and Pagola-Carte, 1999) and Nudibranchia (Schrödl, 1999). This led researchers to consider the biogeographic position of South Georgia as transitional between the Magellan and Antarctic regions. This fact might be related to the convergence in the area of two water masses of different origins: the Weddell Gyre and the West Wind Drift. However, for bivalves it is important to note that the similarity between South Georgia-and other Scotia Arc islands-and the Antarctic Weddell sector were high, ranging from 49 to $88 \%$. Conversely, the similarity found between the Scotia Arc islands and
Patagonia and the Islas Malvinas/Falkland Islands were low (12 to 32\%). Hence, South Georgia and the other Scotia Arc islands appear to be a group that is well differentiated from the Magellan region, justifying their biogeographic placement within the Antarctic region as far as bivalves are concerned.

Based on the biogeographic scheme assumed above and analysing the geographic distribution of the 170 species listed in Table 1, 93 species (54\%) were present in the Magellan region and not in the Antarctic region, 57 species (34\%) were present in the Antarctic region and not in the Magellan region, and only 20 of the total of 170 species $(12 \%)$ were present in both areas. The same analysis at genus level revealed 33 Magellan genera and 7 Antarctic genera.

The differences in the composition of bivalve assemblages reported here for the Magellan and Antarctic regions can be related to the geological history of these areas, which started to separate in the Oligocene (37-23 Ma.) and suffered an intense latitudinal zonation of the shallow-water fauna no later than the Miocene (10-12 Ma) (Crame, 1999). At this time, according to Crame (1999), the development of the Polar Frontal Zone, "one of the strongest natural boundaries in the world ocean", induced some profound biological changes along its course by producing significant vicariant evolutionary processes. Carcelles (1953) suggested that the deep waters of the Drake Passage could also be responsible for differences presently found between the Magellan and Antarctic faunas.

Within this historical scheme, the South Sandwich Islands, an archipelago of volcanic origin, is the youngest among the Scotia Arc islands (1-10 Ma., Ramos, 1996; Udintsev et al., 2000). This fact, together with the great distance from both South America and the Antarctic, could also explain their low species and genera richness. However, it is important to note that the low species and genera richness in the South Sandwich Islands could also originate from the paucity of studies conducted in the archipelago. Furthermore, sampling during the LAMPOS cruise showed that the volcanic bottoms around the South Sandwich Islands, consisting mostly of pumice and lava, may not be an ideal substrate for bivalve molluscs. Also, the values of similarity reported here for South Sandwich are likely to overestimate the actual affinities.

The effects of the West Wind Drift together with the Weddell Gyre might explain the high similarities found between the Scotia Arc islands and the 
Antarctic Weddell sector. Algal rafting represents an effective dispersal mechanism for species living on algae (e. g. Gaimardia trapesina and some species of Philobrya), which distribute eastward following the West Wind Drift. Additionally, transport by fishes has been reported as a dispersal mechanism: Rochefortia charcoti, withstanding passage through the digestive tract of fishes, is passively dispersed in Antarctic environments (Domaneschi et al., 2002). Above all, the West Wind Drift could be potentially contributing to the distribution of species having a planktonic larval stage, a condition so far only reported for a few Antarctic bivalves (e.g. Pearse $e t$ al., 1991), but inferred from protoconch morphology for a few other species (Hain and Arnaud, 1992). Some cases such as Limatula hodgsoni are controversial, having been reported as planktotrophic (Pearse et al., 1991) or lecithotrophic with demersal development (Linse and Page, 2003).

Although the molluscan fauna from the Scotia Arc Islands has been studied since the $19^{\text {th }}$ century, new species of bivalves have recently been described (e.g. Zelaya and Ituarte, 2002, 2003) and several undescribed species have been reported for the area (present study). This, together with the fact that several species are difficult to recognise from their original descriptions and that a significant number of species were not collected again after those descriptions, reveal the need to undertake new and revisive work on the bivalve fauna from the Scotia Arc islands, in order to improve our knowledge of the Antarctic molluscan fauna.

\section{ACKNOWLEDGEMENTS}

The author wishes to thank W. Arntz (AWI) for agreeing to form part of the "LAMPOS 2002" expedition; T. Hromic and E. Mutschke (UMAG) for agreeing to participate in sampling activities in the Straits of Magellan; D. Nahabedian (UBA) for kindly making available the specimens collected by the RV "E. L. Holmberg" in South Georgia; C. Romero, F. Tapella, G. Lovrich (CADIC) and S. Thatje (AWI) for providing samples from Bahía Ushuaia, Beagle Channel, and E. Mutschke, E. Morrison and Y. Cariceo (UMAG) for samples from Punta Arenas, Straits of Magellan. The author especially thanks G. Lovrich and the staff of the Base Naval Ushuaia, particularly M. Matesa and J. Amato, for the assistence offered during samplings at the Beagle Channel. I wish to express my gratitude to C. Ituarte for his help and constructive suggestions and three anonymous reviewers who greatly helped to improve the early version of the manuscript.

\section{REFERENCES}

Arnaud, P. - 1964. Echinodermes littoraux de Terre Adélie (holothuries exceptées) et pélécypodes commensaux d'echinides antarctiques. Expéditions Polaires Françaises (Mission Paul-Emile Victor), 258: 1-69.

Arnaud P.M., K. Jazdzewski, P. Presler and J. Sicinski. - 1986. Preliminary survey of benthic invertebrates collected by Polish Antarctic expeditions in Admiralty Bay (King George Island, South Shetland Islands, Antarctica). Polish Polar Res., 7: 7-24.

Arnaud P.M., J.S. Troncoso and A. Ramos. - 2001. Species diversity and assemblages of macrobenthic Mollusca from the South Shetland Islands and Bransfield Strait (Antarctica). Polar Biol., 24: 105-112.

Arntz, W.E. and T. Brey. - 2003. The expedition ANTARKTIS XIX/5 (LAMPOS) of RV "Polarstern" in 2002. Ber. Polar Meeresforsch., 462: 1-120.

Birkenmajer, K. - 1984. Geology of the Cape Melville area, King Georg Island (South Shetland Islands, Antarctica): pre-Pliocene glaciomarine deposits and their substratum. Studia Geol. Pol., 79: 7-36.

Canteras J. and P. Arnaud. - 1985. Les gastéropodes prosobranches des Îles Kerguelen et Crozet (Sud de 1' Océan Indien): comparaisons écologiques et particularités biologiques. Comité National Français des Recherches Antarctiques, 57: 1-169.

Carcelles, A.R. - 1950. Catálogo de los moluscos marinos de Patagonia. An. Mus. Nahuel Huapí, 2: 41-92.

Carcelles, A.R. - 1953. Catálogo de la malacofauna antártica argentina. An. Mus. Nahuel Huapí, 3: 155-250.

Carcelles, A.R. and S. Williamson. - 1951. Catálogo de los moluscos marinos de la Provincia Magallánica. Rev. Museo Argentino de Ciencias Naturales "Bernardino Rivadavia”, zoología, 2: $225-383$.

Casteló, J. - 1999. Taxonomic study of the isopod crustaceans from the Spanish expedition "Antártida 1986-11" in the Scotia Sea, South Atlantic. Sci. Mar., 63(Suppl. 1): 275-279.

Cheetham, A.H. and J.E. Hazel. - 1969. Binary (presence-absence) similarity coefficients. J. Paleontol., 43(5): 1130-1136.

Clarke, A. - 1996. The distribution of Antarctic marine benthic communities. Foundations for ecological research west of the Antarctic Peninsula. Ant. Res. Ser., 70: 219-230.

Coan, E.V. - 1997. Recent species of the genus Petricola in the Eastern Pacific (Bivalvia: Veneroidea). Veliger, 40(4): 298340 .

Coan, E.V., P.V. Scott and F.R. Bernard. - 2000. Bivalve seashells of western North America. Santa Barbara Museum of Natural History Monographs number 2, Studies in Biodiversity, 2, 764 pp.

Crame, J. A. - 1999. An evolutionary perspective on marine faunal connections between southernmost South America and Antarctica. Sci. Mar., 63(Suppl. 1): 1-14.

Dall, W. - 1914. Mollusca from South Georgia. Sci. Bull. Brooklyn Instit., 2: 69-70.

Dalziel, I.W.D. and D.H. Elliot. - 1971. Evolution of the Scotia Sea. Nature, 233: 246-256.

David, L. - 1934. Zoologische Ergebnisse der Reisen von Dr. KohlLarsen nach den subantarktischen Inseln bei Neuseeland und nach Südgeorgien, part 9. Senckenbergiana, 16(2/3): 126-137.

De Broyer, C. and K. Jazdzewski. - 1993. Contribution to the marine biodiversity inventory. A checklist of the Amphipoda (Crustacea) of the Southern Ocean. Doc. Trav. Inst. roy. Sci. nat. Belg., 73: 1-154.

Dell, R.K. - 1964. Antarctic and sub-Antarctic Mollusca: Amphineura, Scaphopoda and Bivalvia. Discovery Rep., 33: 93-250.

Dell, R.K. - 1990. Antarctic Mollusca with special reference to the fauna of the Ross Sea. Bull. Roy. Soc. N.Z., 27: 1-311.

Domaneschi, O., J.R.M.C. da Silva, L.R.P. Neto and F.D. Passos. 2002. New perspectives on the dispersal mechanisms of the Antarctic brooding bivalve Mysella charcoti (Lamy, 1906). Polar Biol., 25: 538-541. 
Gambôa, L.A.P. and P.R. Maldonado. - 1991. Geophysical investigations in the Bransfield Strait and in the Bellingshausen SeaAntarctica. In: S. John (ed.), Antarctica as an exploration frontier - hydrocarbon potential, geology and hazards. Studies in Geology, 31: 127-141, Tulsa, Oklahoma, American Association of Petroleum Geologists.

Gorny, M. - 1999. On the biogeography and ecology of the Southern Ocean decapod fauna. Sci. Mar. 63 (Suppl. 1): 367-382.

Hain, S. - 1990. The benthic seashells (Gastropoda and Bivalvia) of the Weddell Sea, Antarctica. Ber. Polarforsch., 70: 1-181, pls. 1-30.

Hain, S. and P. Arnaud. - 1992. Notes on the reproduction of high-Antarctic molluses from the Weddell Sea. Polar Biol., 12: 303-312.

Hastings, A. - 1943. Polyzoa (Bryozoa). I. Scrupocellariidae, Epistomiidae, Farciminariidae, Bicellariellidae, Aeteidae, Scrupariidae. Discovery Rep., 22: 301-510, 9 plates.

Hedgpeth, J. - 1969. Distribution of selected groups of marine invertebrates in waters south of $35^{\circ} \mathrm{S}$ latitude. In: Introduction to Antarctic zoogeography, Antarctic Map Folio Series, 11: 144. New York, American Geographical Society. .

Linse, K. - 1997. Distribution of epibenthic Mollusca from the Chilean Beagle Channel. Ber. Polarforsch., 228: 1-130.

Linse, K. - 1999. Mollusca of the Magellan region. A checklist of the species and their distribution. Sci. Mar., 63(Suppl. 1): 399-407.

Linse, K. - 2002. The shelled Magellanic Mollusca: with special reference to biogeographic relations in the Southern Ocean. Theses Zoologicae vol. 74 A.R.A. Ganter Verlag KG, Ruggell, Liechtenstein. 251 pp., 221 pls.

Linse, K. and T.J. Page. - 2003. - Evidence of brooding in Southern Ocean limid bivalves. J. Molluscan Stud., 69: 290-293.

Linse, K., M. Schrödl and D. Zelaya. - 2003. Biodiversity, biogeography and evolution of Mollusca. Ber. Polar Meeresforsch., 462: 19-28.

Martens, E. - 1885. Vorläufige Mittheilungen über die Molluskenfauna von Süd Georgien. S. B. Ges. naturf. Fr. Berlin, 89-94.

Martens, E. and G. Pfeffer. - 1886. Die Mollusken von SüdGeorgien nach der Ausbeute der Deutschen Station 1882-83. J. Hamburg. Wiss. Anst., 3: 66-135.

Melvill, J. and R. Standen. - 1907. The marine Mollusca of the Scottish National Antarctic Expedition. T. Roy. Soc. Edin., 46: 119-157.

Mühlenhardt-Siegel, U. - 1989. Antarktische Bivalvia der Reisen des FS "Polarstern" und des FFS "Walther Herwig" aus den Jahren 1984 bis 1986. Mitt. Hamb. Zool. Mus. Inst., 86: 153-178.

Mühlenhardt-Siegel, U. - 1999. On the biogeography of Cumacea (Crustacea, Malacostraca) - A comparison between South America, the Subantarctic islands and Antarctica: present state of the art. Sci. Mar., 63(Suppl. 1): 295-302.

Narchi, W., O. Domaneschi and F.D. Passos. - 2002. - Bivalves antárticos e subantárticos coletados durante as expedições científicas brasileiras à Antártida I a IX (1982-1991). Rev. Bras. Zool., 19(3): 645-675.

Pearse, J., J. McClintock and I. Bosch. - 1991. Reproduction of Antarctic benthic marine invertebrates: tempos, modes and timing. Amer. Zool., 31: 65-80.

Powell A.W.B. - 1951. Antarctic and Subantarctic Mollusca: Pelecypoda and Gastropoda collected by the ships of the Discovery Committee during the years 1926-1937. Discovery Rep., 26: 49-196.

Powell, A. - 1960. Antarctic and Subantarctic Mollusca. Rec. Aukland Inst. Mus., 5: 117-193.

Preston, H.B. - 1916. Description of eight new species of marine Mollusca from the South Shetland Islands. Ann. Mag. Nat. Hist., Ser.8, Vol.18: 269-272, pl.13.

Ramos, V.A. - 1996. Geología de las islas Sandwich del Sur. XIII Congreso Geológico Argentino y $\mathrm{III}^{\circ}$ Congreso de Exploración de hidrocarburos. In: V.A. Ramos y M.A. Turic (eds.), Geología y Recursos Naturales de la Plataforma Continental Argentina, Capítulo 20: 369-383.

Saiz-Salinas, J.I. and S. Pagola-Carte. - 1999. Sipuncula of the Magellan area compared with adjacent regions of Antarctica. Sci. Mar., 63(Suppl. 1): 227-232.

Schrödl, M. - 1999. Zoogeographic relationship of Magellan Nudibranchia (Mollusca: Opistobranchia) with particular reference to species from adjacent regions. Sci. Mar., 63(Suppl. 1): 409-416.

Schrödl, M. - 2003. Sea Slugs of Southern South America. Conchbooks, Hackenheim. 165 pp.

Soot-Ryen, T. - 1951. Antarctic Pelecypods. Scientific results of the Norwegian Antarctic Expeditions 1927-1928, 32: 1-46 + 1 pl.

Udintsev, G.B., G.W. Schenke, T. Schöne, A.F. Bersnev, P.N. Efimov, A.V. Kol'tsova, A.B. Knyazev, D.E. Teterin, N.A. Kurentsova, A.A. Bulychev and D.A. Gilod. - 2000. Structure of the Scotia Sea bottom, West Antarctic. Doklady Earth Science, 371(2): 411-415.

Winkler, H. - 1994. Charakterisierung der Isopodenfauna (Crustacea, Malacostraca) des Scotia-Bogens aus biogeographischer Sicht: Ein multivariater Ansatz. Ber. Polarforsch., 139: 1-196.

Zelaya, D.G. - 2000. Moluscos de las islas Georgias del Sur: sistemática, biogeografía y ecología. Tesis de Licenciatura, Universidad de Buenos Aires, Facultad de Ciencias Exactas y Naturales, Departamento de Biología: 144 pp.

Zelaya, D.G. and C. Ituarte. - 2002. The identity of Waldo parasiticus (Dall, 1876) and description of Waldo trapezialis new species (Bivalvia: Galeommatoidea). Nautilus, 116(4): 109-117.

Zelaya, D.G. and C. Ituarte. - 2003. Two new species of Neolepton Monterosato, 1875 (Bivalvia: Neoleptonidae) from South Georgia Islands, South Atlantic Ocean. Nautilus, 117(1): 6-11. 